\title{
Geleneksel Yaprak Peynirinin Bazı Karakteristik Özellikleri
}

\section{Bilal KESKİN ${ }^{1}$ Şerafettin ÇELIKK²}

Harran Üniversitesi Mühendislik Fakültesi Gıda Mühendisliği Bölümü, Şanlıurfa, Türkiye ${ }^{1}$ https://orcid.org/0000-0001-6826-9768, ${ }^{2}$ https://orcid.org/0000-0002-5605-5735

$\varangle$ : scelik69@harran.edu.tr

\begin{abstract}
ÖZET
$\mathrm{Bu}$ araştırmada, geleneksel Yaprak peynirinin bazı karakteristik özelliklerinin tespit edilmesi ve gıda güvenilirliği açısından değerlendirilmesi amaçlanmıştır. Bu amaçla, 13 farklı küçük ölçekli süt işletmelerinde inek ve koyun sütünden üretilen geleneksel taze Yaprak peyniri 90 gün süre ile $4{ }^{\circ} \mathrm{C}$ 'de depolanmış ve depolama periyodunun 1., 30., 60., ve 90. günlerinde peynirin bazı karakteristik özellikleri araştırılmıştır. Çiğ inek ve koyun sütünden üretilen olgun Yaprak peynirlerinin ortalama KM, KM'de yağ, protein ve KM'de tuz içerikleri surasıyla \%56.71-58-34, \%40.73-48.19, \%21.37-25.46 ve \%10.46-11.44 aralığında tespit edilmiştir. Depolama periyodu boyunca Yaprak peynirinde asitlik değerlerinin değişim gösterdiği, lipoliz ve proteoliz düzeylerinin ise sürekli artış gösterdiği tespit edilmiştir. Araştırılan mikrobiyolojik parametreler bakımından, depolama periyodunun 90. gününde peynirin tüketime uygunluk arz ettiği sonucuna varılmıştır.
\end{abstract}

\section{Some Characteristic Properties of Traditional Yaprak Cheese}

\section{ABSTRACT}

In this study, it was aimed to determine some characteristics of traditional Yaprak cheese and to evaluate it in terms of food safety. For this purpose, traditional fresh Yaprak cheese produced from cow and sheep milk from 13 different small family plants were collected and stored at $4{ }^{\circ} \mathrm{C}$ for 90 days. On the $1^{\text {st }}, 30^{\text {th }}, 60^{\text {th }}$ and $90^{\text {th }}$ days of storage period, the composition and some biochemical and microbiological properties of the cheese were investigated. The average DM, fat in DM, protein, and salt in DM content of the mature cheeses produced from raw cow and sheep milk were determined in the range of $56.71-58-34 \%, 40.73-48.19 \%, 21.37-25.46 \%$ and $10.46^{-}$ $11.44 \%$ respectively. During the storage period, it was determined that the acidity value varied, and the levels of lipolysis and proteolysis increased continuously. In terms of microbiological parameters, it was concluded that cheese is suitable for consumption on the 90 th day of the storage period.

\section{Araştırma Makalesi}

$\begin{array}{ll}\text { Makale Tarihçesi } \\ \text { Geliş Tarihi } & : 18.05 .2020 \\ \text { Kabul Tarihi } & : 02.07 .2020\end{array}$

\section{Anahtar Kelimeler}

Yaprak peyniri

Telemesi haşlanan peynirler

Gıda güvenliği

Biyokimyasal özellikler

Mikrobiyolojik özellikler

\section{Research Article}

\section{Article History \\ Received : 18.05 .2020 \\ Accepted : $\quad 02.07 .2020$}

Keywords
Yaprak cheese
Pasta filata cheese
Food safety
Biochemical properties
Mikrobiological properties

$\begin{array}{ll}\text { Atıf İçin: } & \text { Keskin B, Çelik Ş 2021. Geleneksel Yaprak Peynirinin Bazı Karakteristik Özellikleri. KSÜ Tarım ve Doğa } \\ & \text { Derg 24 (1): 146-155. https://doi.org/10.18016/ksutarimdoga.vi.739370. } \\ \text { To Cite: } & \text { Keskin B, Çelik Ş 2021. Some Characteristic Properties of Traditional Yaprak Cheese. KSU J. Agric Nat 24 } \\ & \text { (1): 146-155. https://doi.org/10.18016/ksutarimdoga.vi.739370. }\end{array}$

\section{GíRiş}

Peynir, sütün çoğunlukla peynir mayasının etkisiyle prhtılaştırılması, işlenmesi, süzülmesi, şekillendirilmesi, tuzlanması ve farklı sıcaklık ve sürede depolanarak olgunlaştırılması sonucunda elde edilen besin değeri yüksek fermente bir süt ürünüdür. Protein, yağ, mineral maddeler ve vitaminleri konsantre olarak yapisinda bulunduran peynir, beslenmede büyük önem taşımaktadır (Üçüncü 2004).

Türkiyenin yer aldığ̣ coğrafi bölgede, yüzyıllar boyunca kurulan pek çok medeniyetten miras kalan kültürel zenginlik söz konusudur. $\mathrm{Bu}$ bağlamda, Türkiye'de bölge şartları, kültürel alışkanlıklar yetiştirilen hayvan tür ve ırkları ile üretim tekniklerinin farklılı̆̆ nedeniyle, çeşitli yöresel peynirler üretilmektedir. $\mathrm{Bu}$ peynirler, çoğunlukla üretildikleri bölge ile sınırlı kalmış veya yörenin sosyoekonomik durumunun zamanla değişmesine bağlı olarak unutulmaya yüz tutmuştur (Dost ve ark. 2004). Türkiye'de üretim yöntemleri ve karakteristik özellikleri bilinmeyen, değişik yörelerde, farklı tat- 
aroma ve tekstüre sahip 130 civarında geleneksel peynir çeşidinin üretildiği bildirilmektedir (Kamber 2005). Bu peynirlerin büyük bir kısmı, küçük ölçekli süt işletmelerinde veya küçük aile işletmelerinde üretilmektedir. Geleneksel peynirlerin karakteristik özelliklerinin tespit edilmesi ve üretim proseslerinin optimize edilerek süt endüstrisine kazandırılması, yurtiçi ve yurtdışında tanınmasını sağlayacak ve sonuçta ülke ve bölge ekonomilerine önemli katkı sağlayacaktır (Kamber 2005, Hatipoğlu 2014). Geleneksel peynir çeşitlerinin karakterizasyonunun yapılması ve endüstriyel üretime kazandırılması konusunda araştırmalar yapılmaktadır. Bu bağlamda, üretim prosesleri çoğunlukla optimize edilen İzmir tulum peyniri, Dil peyniri, Kaşar peyniri gibi bazı geleneksel peynirlerin orta ve büyük ölçekli işletmelerde üretimi sonucu, güvenilir ve standart kalitede ürün elde edilmesi sağlanmıştır. Halen küçük aile işletmelerinde üretilen ve sevilerek tüketilen, ancak hala tanınmayan ve yöresel olarak üretilip tüketilen geleneksel peynir çeşitliliğinin korunması ve ulusal düzeyde teknolojiye kazandırılması, zengin kültürel mirasın devamı ve peynir teknolojisi açısından önem taşımaktadır.

Değişen koşullar nedeniyle unutulmaya yüz tutmuş, bölgesel olarak üretilen fermente süt ürünlerinin üretim proseslerinin incelenmesi, karakteristik özelliklerinin belirlenmesi, üretim proseslerinin optimize edilerek endüstriyel üretime kazandırılması için çaba sarf edilmelidir. Bu bağlamda yöresel peynirlerin mevcut potansiyelin tespit edilmesi, Türk Gida Kodeksi başta olmak üzere mevcut mevzuatlar çerçevesinde teknolojik iyileştirmeler sonucu standart kalitede üretimlerinin gerçekleştirilmesi iç ve dış ticaret imkânlarının geliştirilmesine katkı sağlayacaktır.

Türk Gıda Kodeksi Peynir Tebliği'nde, 'telemesi haşlanan peynirlerin taze olarak tüketime arz edilebileceği' anlaşılmaktadır (Anonim 2015). Ancak üretim ve depolama şartlarında hijyenik şartlara gereken özenin gösteril(e)memesi nedeniyle, rekontaminasyon olabileceği ve bu tip peynirlerinde tüketici sağllğ oluşturabileceği düşünülmektedir. Bu nedenle, gıda güvenliği indikatörleri olarak bilinen bakteri ve bakteri gruplarının varlığ değerlendirilmesi önem taşımaktadır.

Yöresel olarak üretilen geleneksel peynirlerden biri de Karacadağ bölgesinde üretilen ve çoğunlukla üretildiği bölgede tüketilen Yaprak peyniridir. $\mathrm{Bu}$ peynir, çoğunlukla ilkbahar aylarında ağırlıklı olarak çiğ koyun sütünden üretilmektedir. Peynir üretiminde, fermente teleme yüksek sicaklıkta haşlandıktan sonra, teleme hamuru düz zemin üzerinde oklava ile açılarak düzleştirilmekte, ortalama $0.5 \mathrm{~cm}$ kalınlık ve $5 \times 5 \mathrm{~cm}$ ebadında porsiyonlar halinde kesildikten sonra salamurada muhafaza edilmektedir. Peynir taze veya
4-6 ${ }^{\circ} \mathrm{C}$ 'de 2-3 ay süre ile depolandıktan /olgunlaştırıldıktan sonra tüketime arz edilmektedir. $\mathrm{Bu}$ peynir ile ilgili yapılmış herhangi bir çalışmaya rastlanmamıştır.

$\mathrm{Bu}$ çalışmada, Yaprak peyniri florasında istenmeyen kontaminantların varlığ peynirin bileşim ve bazı biyokimyasal özelliklerinin tespit edilmesi ve araştırılan parametreler bağlamında peynirin Türk Gıda Kodeksi Peynir Tebliği (Anonim 2015) ile Türk Gıda Kodeksi Mikrobiyolojik Kriterler Yönetmeliği (Anonim 2011) bağlamında irdelenmesi ve literatüre kazandırılması amaçlanmıştır.

\section{MATERYAL ve METOD}

\section{Materyal}

$\mathrm{Bu}$ çalı̧̧ma kapsamında, geleneksel peynirinin üretildiği 13 küçük aile işletmesinden (13 örnek koyun sütünden yapılan peynir, 13 örnek inek sütünden yapılan peynir) Yaprak peyniri örnekleri alınmıştır. Taze peynir örnekleri (1.gün) işletme şartlarında plastik bidonlara $(3 \mathrm{~kg})$ alınmış ve $4 \quad{ }^{\circ} \mathrm{C}$ 'de depolanmıştır.

\section{Metot}

\section{Bileşim Analizleri}

Geleneksel Yaprak peyniri örneklerinde bileşim analizleri depolama periyodunun 90. gününde yapılmıştır. Bu bağlamda, peynir örneklerinde KM, yağ, protein (Dumas yöntemi), kül ve tuz (Mohr yöntemi), KM'de yağ ve KM'de tuz oranları yapılmıştır (Anonim 1989). KM'de yağ ve KM'de tuz oranları hesapla bulunmuştur.

\section{Biyokimyasal Analizler}

Peynir örneklerinde, titrasyon asitliği ve $\mathrm{pH}$ analizleri (Anonim 1989) ile proteoliz ve lipoliz düzeyleri, depolama periyodunun 1., 30., 60. ve 90. günlerinde yapılmıştır. Peynir örneklerinde $\mathrm{pH}$ 4.6'da çözünen azot (ÇA) oranı Gripon ve ark. (1975) ve FIL-IDF (1993), TCA'da ÇA oranı ise Anonim (1989) tarafindan önerilen yöntemlere göre yapılmıştır. Elde edilen tüm filtratlar, analize alınincaya kadar $-20^{\circ} \mathrm{C}$ 'de muhafaza edilmiştir. Olgunlaşma indeksi, depolama periyodunun 90. gününde elde edilen $\mathrm{pH} 4.6$ 'da ÇA'un toplam azota bölünmesi ve 100 ile çarpılması sonucu bulunmuştur. Peynir örneklerinde lipoliz düzeyi (asit değeri), Coşkun (1995) tarafindan önerilen yönteme göre yapılmıştır.

\section{Mikrobiyolojik Analizler}

Geleneksel Yaprak peyniri örneklerinde mikrobiyolojik analizler, depolama periyodunun 1., 30., 60. ve 90. günlerinde yapılmıştır.

Geleneksel Yaprak peyniri örneklerinden ilk dilüsyon 
$\left(10^{-1}\right)$ hazırlamak için, steril $\% 2(\mathrm{w} / \mathrm{v})$ sodyum sitrat kullanılmış, daha sonra steril peptonlu su (\%0.1) kullanılarak uygun dilüsyonlar hazırlanarak spesifik besiyerlerine ekim yapılmıştır (Caridi 2003, Gerasi ve ark. 2003).

Peynir florasında Lactobacillus cinsi bakteri sayımı için MRS agar besiyerine $\left(37^{\circ} \mathrm{C}\right.$ 'de 48 saat), kok şekilli laktik asit bakterileri için ise M17 agar $\left(37{ }^{\circ} \mathrm{C}\right.$ 'de 48 saat) besiyerine dökme plak yöntemiyle ekim yapılmış ve anaerobik şartlarda inkübasyona bırakılmıştır. Koliform ve fekal koliform grubu bakterilerin sayımı amacıyla VRBA besiyerine ekim yapılmıştır. Koliform grubu için $30{ }^{\circ} \mathrm{C}$ 'de 24 saat, fekal koliform grubu için ise $44{ }^{\circ} \mathrm{C}$ 'de 24 saat inkübasyon normu uygulanmıştır. Maya-küf sayımları için, tartarik asitle (\%10'luk, 14 $\mathrm{mL} \mathrm{L}^{-1}$ ) asitliği $\mathrm{pH}$ 3.5'e ayarlanmış, PDA besiyerine ekim yapılarak $25{ }^{\circ} \mathrm{C}$ 'de 5 gün inkübasyona bırakılmıştır (Caridi 2003, Gerasi ve ark. 2003). E. coli varlığı ve sayımı için, uygun dilüsyondan Chromocult TBX agar besiyerine dökme plak yöntemiyle ekim yapıldıktan sonra, $44^{\circ} \mathrm{C}$ 'de 24 saat inkübe edilmiştir (Vural ve ark. 2010). İnkübasyon sonrası, petrilerde doğrudan koloni sayımı yapılmıştır.

Koagulaz (+) Staphylococcus tespiti için, $25 \mathrm{~g}$ peynir örneği $225 \mathrm{~mL}$ steril sodyum sitrat içinde homojenize edilmiş, Baird Parker (BP) Agar (Oxoid CM 0275, egg yolk tellurite supl. SR 0054) besiyerine yüzeye yayma yöntemiyle ekim yapılmış ve $35-37{ }^{\circ} \mathrm{C}$ 'de $24-48$ saat inkübe edilmiştir. İnkübasyon sonrası petrilerde atipik ve tipik koloniler sayılarak doğrulama işlemine geçilmiştir. Doğrulama işlemi için izolatlar, Brain Heart Infusion besiyeri tüpüne aktarılarak $35-37^{\circ} \mathrm{C}$ 'de $24 \pm 2$ saat süre ile inkübe edilmiştir. Daha sonra 0.1 $\mathrm{mL}$ steril hemoliz tüplerine ( $0.3 \mathrm{~mL}$ tavşan plazması) aktarılmış ve $35{ }^{\circ} \mathrm{C}$ 'de inkübasyona bırakılmıştır. Tüpler eğik tutularak inkübasyonun 4-6 saati arasında plazmanın pihtılaşıp pıhtılaşmadığı incelenmiştir (Anonim 2001).

\section{Istatistiksel Analizler}

Çalışmaya ait veriler, çift yönlü ANOVA ile analiz edilmiş, önemli bulunan ortalamalar arasındaki farklılık Tukey çoklu karşılaştırma testi ile belirlenmiştir (Yıldız ve Bircan 1994). Analiz öncesi mikrobiyolojik parametrelere ait veriler, logaritmik transformasyona tabi tutulmuştur. Varyans analizi için MINITAB paket programı kullanılmıştır.

\section{BULGULAR ve TARTIŞMA}

\section{Bileşim}

Çiğ inek ve koyun sütlerinden üretilen Yaprak peynirlerin bileşim parametrelerine ilişkin ortalama değerler ve oluşan gruplar Çizelge 1'de verilmiştir.

Çizelge 1. Çiğ inek ve koyun sütlerinden üretilen geleneksel olgun Yaprak peynirinin bileşimine ait ortalama değerler (\%) ve oluşan gruplar

Table 1. Groups formed and average mean values (\%) of the composition of traditional mature Yaprak cheeses made from raw cow or sheep milk

\begin{tabular}{llllllll}
\hline $\begin{array}{l}\text { Peynir } \\
\text { Cheese }\end{array}$ & $\begin{array}{l}\text { KM } \\
\text { DM }\end{array}$ & $\begin{array}{l}\text { Protein } \\
\text { Protein }\end{array}$ & $\begin{array}{l}\text { Yağ } \\
\text { Fat }^{2}\end{array}$ & $\begin{array}{l}\text { KM'de Yağ } \\
\text { Fat in DM }^{2}\end{array}$ & $\begin{array}{l}\text { Kül } \\
\text { Ash }\end{array}$ & $\begin{array}{l}\text { Tuz } \\
\text { Salt }\end{array}$ & $\begin{array}{l}\text { KM'de Tuz } \\
\text { Salt in DM }\end{array}$ \\
\hline $\begin{array}{l}\text { Inek peyniri } \\
\text { Cow cheese }\end{array}$ & $58.34 \pm 0.60$ & $21.37 \pm 0.37^{\mathrm{b}}$ & $28.06 \pm 0.46^{\mathrm{a}}$ & $48.19 \pm 0.52^{\mathrm{a}}$ & $8.71 \pm 0.12^{\mathrm{a}}$ & $6.73 \pm 0.12^{\mathrm{a}}$ & $11.44 \pm 0.27^{\mathrm{a}}$ \\
\hline $\begin{array}{l}\text { Koyun peyniri } \\
\text { Sheep cheese }\end{array}$ & $56.71 \pm 0.60$ & $25.46 \pm 0.37^{\mathrm{a}}$ & $23.14 \pm 0.46^{\mathrm{b}}$ & $40.73 \pm 0.52^{\mathrm{b}}$ & $7.95 \pm 0.12^{\mathrm{b}}$ & $5.91 \pm 0.12^{\mathrm{b}}$ & $10.46 \pm 0.27^{\mathrm{b}}$ \\
\hline
\end{tabular}

KM: Kurumadde; DM: Dry matter

Farklı lokasyonlarda faaliyet gösteren küçük ölçekli işletmelerde üretilen ve 3 ay boyunca depolanan olgun Yaprak peynirinin ortalama KM oranı, inek sütünden yapılan peynirde $\% 58.34$, koyun sütünden yapılan peynirde ise bu değer ortalama \%56.71 olarak hesaplanmıştır. İnek sütüne oranla, koyun sütünün yağ oranı daha yüksek olması nedeniyle (Üçüncü 2004), koyun sütünden üretilen Yaprak peynirinin KM oranının da daha yüksek olması beklenmektedir. Ancak, söz konusu peynir üretiminin yapıldı̆̆ Karacadağ bölgesinde koyun sütünden sadeyağ üretimi de yaygın olarak yapılmaktadır (Hatipoğlu 2014). Bu nedenle, peynir üretiminde kullanılan koyun sütünün belirli düzeyde yağ $\breve{g}_{1}$ alınmaktadır. Ortalama KM oranı, Diyarbakır Örgü peynirinde \%44.83 (Özdemir ve ark. 1998), \%52.73 (Çelik ve Türkoğlu 2007) ve \%54.43 (Hatipoğlu 2014), Dil peynirinde ise bu oran \%53.95 (Uysal 2008) olarak bildirilmiştir. Peynirin KM oranındaki bu farklılık, sütün türü, sütün yağ oranı ve peynirin depolama süresinden kaynaklanmış olabilir. Türk Gıda Kodeksi Peynir Tebliği'nde (Anonim 2015) fermente telemesi haşlanan ve salamurada olgunlaştırılan peynirlerde KM oranının en az \%55 olması gerektiği bildirilmektedir. $\mathrm{Bu}$ bağlamda, inek ve koyun sütünden üretilen Yaprak peynirleri anılan tebliğe uygunluk arz etmekte ve adı geçen tebliğe göre sert peynir sinıfında yer almaktadır.

İnek sütünden yapılan geleneksel Yaprak peynirinde ortalama protein oranı, koyun sütünden yapllan peynire oranla, çok önemli düzeyde $(\mathrm{P}<0.01)$ daha düşük bulunmuştur. Ortalama protein oranı, Diyarbakır Örgü peynirinde \%21.69 (Özdemir ve ark. 1998), \%22.48 (Celik ve Türkoğlu 2007) ve \%25.20 (Hatipoğlu 2014); Dil peynirinde \%24.24 (Uysal 2008) olarak bildirilmiştir. Ortaya çıkan bu durum, süt hayvanlarının ırkı/türü ve hayvan yeminin farklı olmasından kaynaklanmış olabilir. 
Geleneksel Yaprak peynirinin ortalama yă̆ oranı, inek sütünden üretilen peynirde çok önemli düzeyde $(\mathrm{P}<0.01)$ daha yüksek hesaplanmıştır (Çizelge 1). Karacadağ bölgesinde Yaprak peyniri ile sadeyağ üretiminin yaz aylarının başlangıcında eşzamanlı olarak başladığı, özellikle koyun sütünün belirli düzeyde kreması alınarak kaymak, tereyağı veya sadeyağa işlendiği, bölge peynir üreticileri tarafından belirtilmektedir. Dolayısıyla, yağı alınmış koyun sütünden üretilen peynirde de yağ oranının düşük olması beklenmektedir. Diyarbakır Örgü peynirinde ortalama yağ oranı, Özdemir ve ark. (1998) \%14.72, Çelik ve Türkoğlu (2007) \%21.73, Hatipoğlu (2014) ise \%20.57, Dil peynirinde bu oran Uysal (2008) tarafından \%23.50 olarak bildirilmiştir.

İnek sütünden üretilen Yaprak peynirin KM'de yağ oranı, koyun sütünden üretilen peynire oranla, çok önemli düzeyde $(\mathrm{P}<0.01)$ daha yüksek bulunmuştur. Karacadağ bölgesinde üretilen ve üretim prosesi bakımından Yaprak peyniri ile benzerlik gösteren Diyarbakır Örgü peynirinde ortalama KM'de yağ oranı \%32.23 (Özdemir ve ark. 1998), \%41.20 (Çelik ve Türkoğlu 2007) ve \%37.73 (Hatipoğlu 2014) olarak bildirilmiştir. KM'de yağ oranı bakımından, Türk Gıda Kodeksi Peynir Tebliği’nde belirtilen ölçütlere göre, inek sütünden elde edilen Yaprak peyniri tam yağ $l_{l}$ (en az \%45 yağll), koyun sütünden üretilen peynir ise yarım yağlı sınıfta yer almaktadır (Anonim 2015).

Koyun ve inek sütünden yapılan Yaprak peynirlerinde ortalama kül oranları çok önemli düzeyde $(\mathrm{P}<0.01)$ farklılık göstermiştir (Çizelge 1). Bu durum, peynirlerde tuz oranınin farklı olmasindan kaynaklamış olabilir. Benzer durum, aynı bölgede üretilen peynirlerde de gözlenmiştir (Özdemir ve ark. 1998, Çelik ve Türkoğlu 2007, Uysal 2008, Hatipoğlu 2014).

İnek sütünden üretilen Yaprak peynirinde ortalama tuz ve KM'de tuz oranları istatistiksel olarak önemli düzeyde $(\mathrm{P}<0.05)$ yüksek bulunmuştur. KM'de tuz oranı, Karacadağ bölgesinde çĭ̆ sütten benzer yöntemlerle üretilen Diyarbakır Örgü peynirinde \%13.68 (Özdemir ve ark. 1998), \%13.18 (Çelik ve Türkoğlu 2007) ve \%14.13 (Hatipoğlu 2014) olarak hesaplanmıştır. İnek ve koyun sütleri kullanılarak üretilen Yaprak peyniri için hesaplanan KM'de tuz oranları, Türk Gıda Kodeksi Peynir Tebliği'nde fermente telemesi haşlanan ve salamurada olgunlaştırılan peynirler için belirlenen limit orandan (en fazla \%7.5) daha yüksek bulunmuştur (Çizelge 1). $\mathrm{Bu}$ bağlamda, bu peynir ile ilgili yapllacak olan çalışmalarda bu durumun dikkate alınması ve bu doğrultuda bilimsel çalışmaların yapılması mer’i mevzuata uygunluk bakımından zorunluluk arz etmektedir.

\section{Biyokimyasal Özellikler}

Çiğ inek ve koyun sütlerinden üretilen geleneksel Yaprak peynirinin bazı biyokimyasal özelliklerine ait ortalama değerler ve oluşan gruplar Çizelge 2'de verilmiştir.

Çizelge 2. Çiğ inek ve koyun sütlerinden üretilen geleneksel Yaprak peynirinin bazı biyokimyasal özelliklerine ait ortalama değerler ve oluşan gruplar

Table 2. Groups formed and average mean values of some biochemical properties of traditional Yaprak cheeses pruduced from raw cow or sheep milk

\begin{tabular}{|c|c|c|c|c|c|}
\hline & $\begin{array}{l}\text { TA } \\
\text { TA }\end{array}$ & $\begin{array}{l}\mathrm{pH} \\
\mathrm{pH}\end{array}$ & $\begin{array}{l}\text { Asit değeri } \\
\text { Acid value } \\
\left.\text { (mg KOH g-yağ }{ }^{-1}\right)\end{array}$ & $\begin{array}{l}\text { pH } 4.6 \text { 'da ÇA } \\
\text { SN in pH } 4.6 \\
(\%)\end{array}$ & $\begin{array}{l}\text { TCA'da ÇA } \\
\text { SN in TCA (\%) }\end{array}$ \\
\hline İnek peyniri (Cow cheese) & $0.09 \pm 0.002^{b}$ & $5.11 \pm 0.02$ & $1.14 \pm 0.08^{\mathrm{b}}$ & $0.94 \pm 0.04$ & $1.26 \pm 0.03$ \\
\hline Koyun peyniri(Sheep cheese) & $0.11 \pm 0.002^{\mathrm{a}}$ & $5.08 \pm 0.02$ & $1.89 \pm 0.08^{\mathrm{a}}$ & $0.85 \pm 0.04$ & $1.23 \pm 0.03$ \\
\hline
\end{tabular}

TA: Titrasyon asitliği (\%LA), ÇA: Çözünen azot; Titratable acidity (lactic acid \%), SN: Soluble nitrogen

Çizelgede görüldüğü gibi, koyun sütünden üretilen Yaprak peynirine oranla, inek sütünden yapılan peynirde titrasyon asitliği çok önemli düzeyde $(\mathrm{P}<0.01)$ daha düşük bulunmuştur. Koçak ve ark. (1997) Dil peynirinde, Özdemir ve ark. (1998), Aksu ve ark. (1999) ile Türkoğlu ve ark. (2003) Örgü peynirinde ve Çelik ve ark. (2001) ise Lavaş peynirinde ortalama titrasyon asitliğini (SH) sirasıyla 22.89, 22.86, 15.11, 49.33 ve 22.74 olarak bildirmişlerdir. Bu çalışmada, Yaprak peyniri için hesaplanan titrasyon asitliği değerleri, literatürde benzer peynirler için bildirilen değerlerden daha yüksek bulunmuştur. Bu durum, üretimde kullanılan çiğ sütün asitliği, mevsim ve depolama sıcaklıklarının farklılı̆̆ından kaynaklanmış olabilir.
İnek ve koyun sütünden üretilen Yaprak peynirinin titrasyon asitliği, depolama periyodunun 30 . gününde nispeten yükselmiş, daha sonra 60. günde hızlı bir azalma, periyodun sonunda ise yavaş bir yükselme görülmüştür (Şekil 1). Proteoliz nedeniyle oluşan alkali ve nötral karakterli bileşikler ile lipoliz sonucu ortaya çıkan parçalanma ürünlerinin titrasyon asitliğinin düşmesine neden olabildiği bildirilmiştir (Güven ve Konar 1994, Uysal 2008). Bu durum, farklı çalışmalarda da benzer şekilde ortaya konmuştur (Tarakçı ve Küçüköner 2006, Çelik ve Türkoğlu 2007, Uysal 2008, Fresno ve Alvarez 2012, Hatipoğlu 2014). İnek ve koyun sütünden yapılan Yaprak peynirlerinde ortalama $\mathrm{pH}$ değerleri birbirine çok yakın bulunmuştur (Çizelge 2). Elde edilen bu sonuçlara 
benzer olarak, Çelik ve Türkoğlu (2007) çiğ sütten yapılan Örgü peynirinin ortalama $\mathrm{pH}$ değerini 5.07; Hatipoğlu (2014) ise Diyarbakır Örgü peynirinde ortalama $\mathrm{pH}$ değerini 5.57 olarak bildirmişlerdir. Uysal (2008) çiğ sütten yapılan Dil peynirinin ortalama $\mathrm{pH}$ değerini 5.07, saha çalışması niteliğindeki bir araştırmada ise Dil peynirinin ortalama asitliği pH 5.20 olarak bildirilmiştir (Koçak ve ark. 1997).

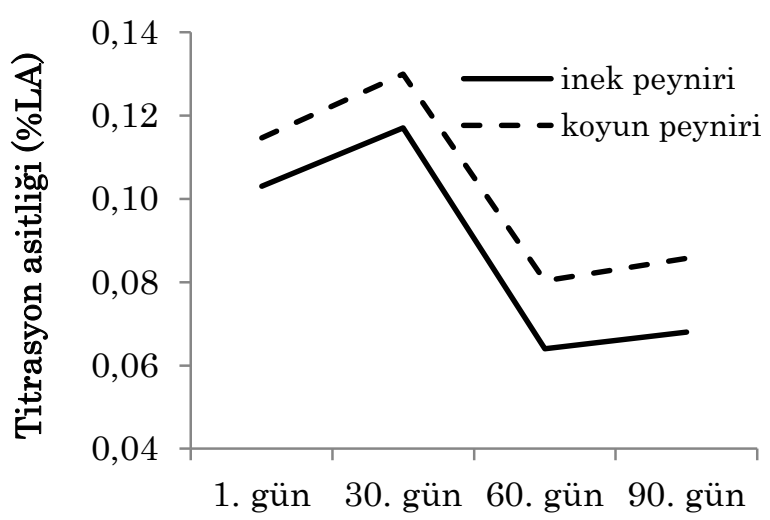

\section{Depolama periyodu}

Şekil 1. Farklı tür sütten üretilen Yaprak peynirinde titrasyon asitliğinin depolama periyodu boyunca değişimi

Figure 1. The changes in titratable acidity of Yaprak cheeses made from diffrent types of milk during storage period

İnek sütünden üretilen Yaprak peynirinin $\mathrm{pH}$ değeri, depolama periyodunun 60. gününe kadar nispeten yükselmiş, daha sonra azalmıştır. Koyun sütünden yapılan peynirde ise, periyodun 30. gününe kadar sabit seyretmiş, daha sonra periyodun sonuna kadar hızlı bir şekilde azalmıştır (Şekil 2). Benzer şekilde, çiğ sütten üretilen Örgü peynirinde olgunlaşma periyodunun 15. gününde $\mathrm{pH}$ değerinin yükseldiği ve daha sonra periyodun sonuna kadar azalma eğilimi görüldüğü (Çelik ve Türkoğlu 2007); başka bir çalışmada ise çiğ sütten elde edilen Dil peynirinde $\mathrm{pH}$ değerinin olgunlaşma periyodunun 60. gününe kadar çok önemli düzeyde arttığı, periyodun 90 . gününde ise bu değerin nisbi olarak azaldığı bildirilmiştir (Uysal 2008).

Koyun sütünden yapılan peynirde lipoliz düzeyi (asit değeri, mg KOH g-yă $\left.\breve{g}^{-1}\right)$, çok önemli düzeyde $(\mathrm{P}<0.01)$ daha yüksek bulunmuştur (Çizelge 2). İnek sütünden yapılan Yaprak peyniri için hesaplanan ortalama asit değerleri, Çelik ve Türkoğlu (2007) tarafından çiğ sütten yapılan Örgü peyniri için bildirilen ortalama değerden (1.49 mg KOH g-yağ-1) düşük, koyun sütünden üretilen Yaprak peyniri için hesaplanan ortalama asit değeri ise daha yüksek bulunmuştur. Ayrıca inek ve koyun sütünden yapılan Yaprak peyniri için hesaplanan ortalama lipoliz düzeyleri, Uysal (2008) çiğ sütten yapılan Dil peyniri için bildirilen ortalama değerden $(0.25 \mathrm{mg} \mathrm{KOH} \mathrm{g-yağ-1)} \mathrm{daha} \mathrm{düşük}$ bulunmuştur. Asit değeri, peynir üretiminde uygulanan fermantasyon ve haşlama işlemi başta olmak üzere haşlama öncesi fermantasyon düzeyi, peynir üretim prosesleri ile işletmede uygulanan hijyen ve sanitasyon işlemlerinden etkilenmektedir.

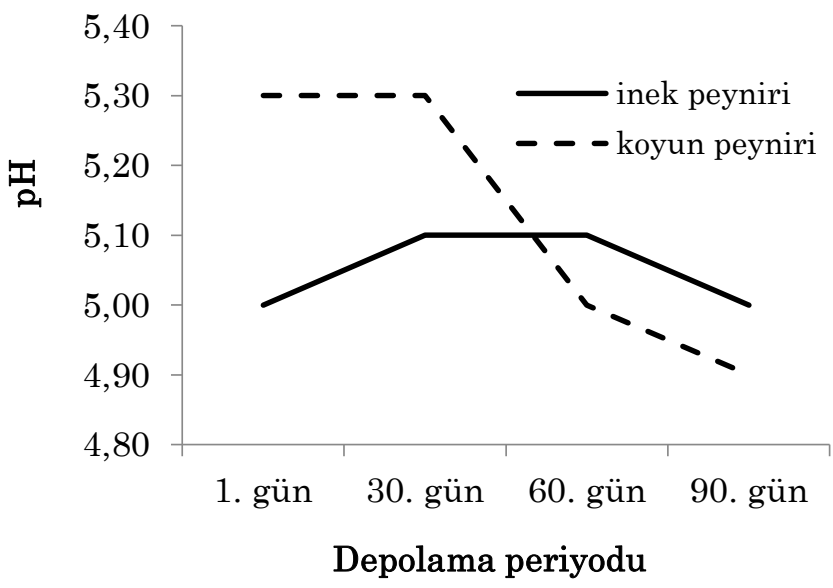

Şekil 2. Farklı tür sütten üretilen Yaprak peynirinde $\mathrm{pH}$ değerinin depolama periyodu boyunca değişimi

Figure 2. The changes in pH of Yaprak cheeses made from diffrent types of milk during storage period

İnek ve koyun sütünden üretilen Yaprak peynirinin asit değeri, depolama periyodu boyunca yükselmekle beraber, koyun sütünden üretilen peynirde daha yüksek seyretmiştir (Şekil 3). Benzer şekilde, Çelik ve Türkoğlu (2007) Örgü peynirinde, Uysal (2008) Dil peynirinde 90 günlük depolama süresi boyunca asit değerlerinin önemli bir şekilde artış gösterdiğini bildirmişlerdir.

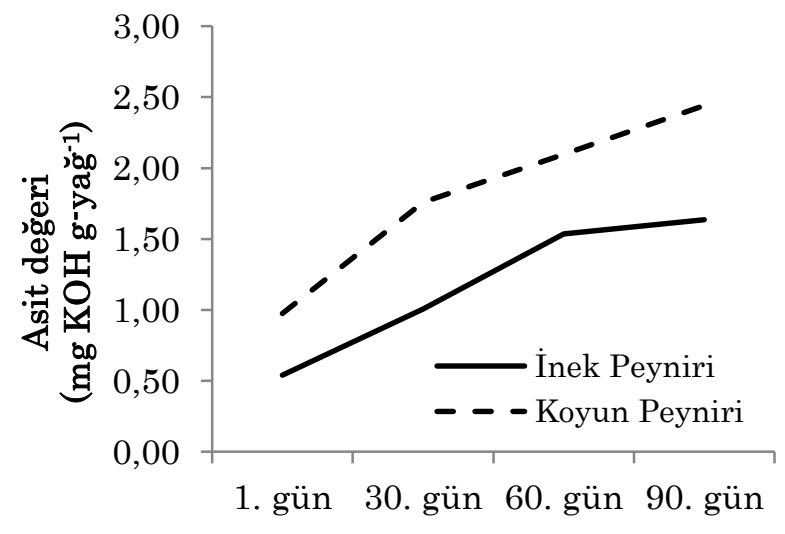

\section{Depolama periyodu}

Şekil 3. Farklı tür sütten üretilen Yaprak peynirinde asit değerinin depolama periyodu boyunca değişimi

Figure 3. The changes in acidity value of Yaprak cheeses made from diffrent types of milk during storage period

Koyun ve inek sütlerinden üretilen Yaprak peynirlerinin ortalama $\mathrm{pH} 4.6$ 'da ÇA oranları arasında önemli bir farklılık bulunmamıştır (Çizelge 2). 
Geleneksel Yaprak peynirinin $\mathrm{pH}$ 4.6'da ÇA oranları, Uysal (2008)'ın Dil peyniri için bildirdikleri değerlerden (\%0.12-0.13) yüksek bulunmuştur. $\mathrm{pH}$ 4.6'da ÇA oranlarının yüksek bulunması, peynirin çiğ sütten yapılmasından kaynaklanmış olabilir. $\mathrm{Bu}$ bağlamda, çiğ sütten üretilen Cheddar peynirinde, starter olmayan laktik asit bakteri sayısı ile küçük molekülllü peptitler, aminoasitler ve serbest yağ asitleri miktarı arasında pozitif bir ilişki ortaya konmuştur (McSweeney ve ark. 1993).

Depolama periyodunun başlangıcında koyun sütünden üretilen Yaprak peynirinde $\mathrm{pH}$ 4.6'da çözünen azot oranının daha düşük olduğu, ancak periyodun 90 . gününde bu oran koyun sütünden elde edilen peynirde daha yüksek bulunmuştur (Şekil 4). Uysal (2008) çiğ sütten yapılan Dil peynirde $\mathrm{pH} 4.6$ 'da ÇA oranının, taze peynirde (1.gün) $\% 0.13$, olgun peynirde ise (90.gün) nispi bir artış gözleyerek \%0.14 olduğunu bildirmişlerdir.

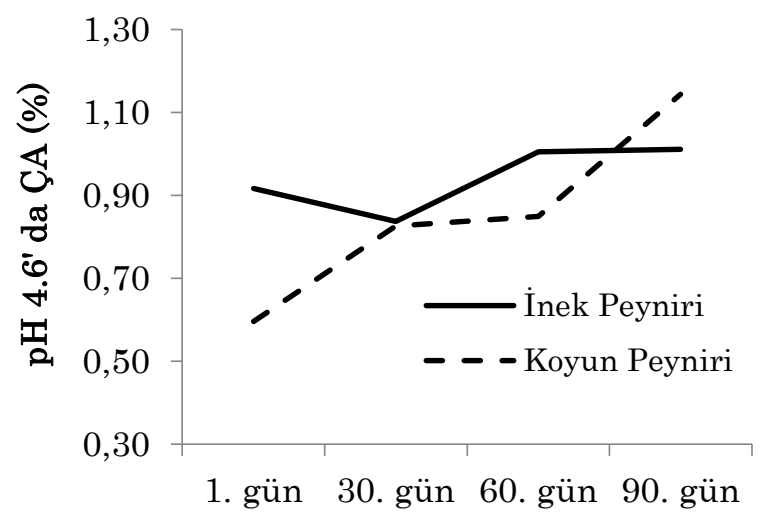

Depolama periyodu

Şekil 4. Farklı tür sütten üretilen Yaprak peynirinde $\mathrm{pH}$ 4.6 'da çözünen azot oranının depolama periyodu boyunca değişimi

Figure 4. The changes in SN in pH 4.6 of Yaprak cheeses made from diffrent types of milk during storage period

Çiğ inek ve koyun sütünden yapılan Yaprak peynirinin ortalama TCA'da ÇA oranları birbirine çok yakın bulunmuştur. TCA'da-ÇA oranı bakımından, çiğ sütten üretilen Cheddar (McSweeny ve ark. 1993), Manchego (Gaya ve ark. 1990) ve Kasseri (Moatsou ve ark. 2011) peynirlerinde bu oranın daha yüksek olduğu bildirilmesine karşın, çiğ ve pastörize sütten üretilen Cheddar (Rosenberg ve ark. 1995) ve Kaşar (Sert ve ark. 2007) peynirlerinde bu parametre bakımından herhangi bir farklılık tespit edilmediği bildirilmiştir. Protein olmayan azot olarak da bilinen TCA'da ÇA, düşük molekül ağırlıklı proteoliz ürünlerinin konsantrasyonunu belirlemek ve peynirin olgunluk düzeyini tespit etmek için kullanılan önemli bir parametredir.

Farklı tür sütlerden üretilen Yaprak peynirinin TCA'da ÇA oranı, depolama periyodu boyunca sürekli yükselmiştir (Şekil 5). Çiğ sütten yapılan ve 90 gün süre ile depolanan Örgü peynirlerinde ortalama TCA'da ÇA oranının yükseldiği (Çelik ve Türkoğlu 2007); çĭ̆ sütten yapılan Dil peynirinde olgunlaşma periyodunun 30. gününe kadar TCA'da ÇA değerlerinin değişkenlik göstermediği, daha sonra ise arttığ̣ bildirilmiş̧tir (Uysal 2008).

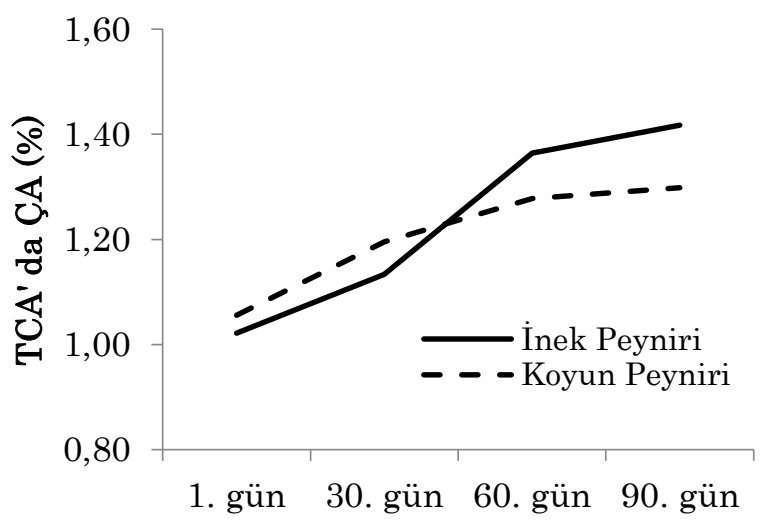

Depolama periyodu

Şekil 5. Farklı tür sütten üretilen Yaprak peynirinde TCA'da çözünen azot oranının depolama periyodu boyunca değişimi

Figure 5. The changes in SN in TCA of Yaprak cheeses made from diffrent types of milk during storage period

Olgunlaşma indeksi peynir teknolojisinde proteolitik aktivitenin ve buna bağlı olarak olgunlaşmanın bir göstergesi olarak kabul edilmektedir (Üçüncü 2004). Olgunlaşma indeksi, inek sütünden yapılan Yaprak peynirinde $\% 26.87$, koyun sütünden yapılan peynirde ise \%30.08 olarak hesaplanmıştır. Olgunlaşma indeks, taze ve olgun (90 günlük) Kaşar peynirinde \%10.5010.59 ve \%18.70-20.95 arasında bildirilmiştir (Tarakçı ve Küçüköner 2006). Dil (Koçak ve ark. 1997), Diyarbakır Örgü (Özdemir ve ark. 1998) ve Lavaş (Çelik ve ark. 2001) peynirlerinde ortalama olgunlaşma indeksi sırasıyla, \%12.45, 3.09 ve 2.30 olarak bildirilmiştir.

\section{Mikrobiyolojik Özellikler}

Farklı tür sütlerden üretilen geleneksel Yaprak peynirinin mikrobiyolojik parametrelerine ilişkin ortalama değerler ve oluşan gruplar Çizelge 3'te verilmiştir.

İnek sütünden yapılan Yaprak peynirinde ortalama Lactococcus sp. ve Lactobacillus sp. sayısı (log kob g-1) sirasiyla $6.23 \pm 0.09$ ve $5.76 \pm 0.09$ olduğu; koyun sütünden üretilen Yaprak peynirinde ise sayı sirasıyla $6.41 \pm 0.09$ log kob g ${ }^{-1}$ ve $5.74 \pm 0.09$ log kob g-1 olarak tespit edilmiştir (Çizelge 3).

Yaprak peynirlerinde Lactococcus sp. bakteri yükü (log kob g-1), olgunlaşma süresi boyunca nisbi bir azalma eğilimi göstermiştir. Ortaya çıkan bu sonuç 
olgunlaşma periyodunun sonuna kadar Lactococcus $s p$. azaldığını bildiren bazı araştırıcıların (Ortigosa ve ark. 2006, Öner ve ark. 2006, Calvo ve ark. 2007) bulgularıla benzerlik gösterirken, diğer bazı araştırıcıların (Güven ve Konar 1994, Marino ve ark.
2003, Uysal 2008) bulgularindan farklılık göstermiştir. Bulgularda gözlemlenen bu farklılık, uygulanan teknolojik işlemlerden ve kullanılan çiğ sütün kalitesinden kaynaklanmış olabilir.

Çizelge 3. Farklı tür sütlerden üretilen Yaprak peynirinin bazı mikrobiyolojik parametrelerine ait ortalama değerler ve oluşan gruplar (log kob g-1)

Table 3. Groups formed and average values $\left(\log \mathrm{cfu}^{-1}{ }^{-1}\right.$ of some microbiological parameters of Yaprak cheeses made from raw cow or sheep milk

\begin{tabular}{lllllll}
\hline & Lactococcus sp. & Lactobacillus sp. & $\begin{array}{l}\text { KGB } \\
\text { B }\end{array}$ & $\begin{array}{l}\text { FKGB } \\
\boldsymbol{F C B}\end{array}$ & E. coli & $\begin{array}{l}\text { Maya-Küf } \\
\text { Mould-Yeast }\end{array}$ \\
\hline $\begin{array}{l}\text { Inek peyniri } \\
\text { Cow cheese }\end{array}$ & $6.23 \pm 0.09$ & $5.76 \pm 0.09$ & $2.80 \pm 0.12^{\mathrm{a}}$ & $2.54 \pm 0.10^{\mathrm{a}}$ & $2.21 \pm 0.11^{\mathrm{a}}$ & $2.10 \pm 0.10^{\mathrm{a}}$ \\
\hline $\begin{array}{l}\text { Koyun peyniri } \\
\text { Sheep cheese }\end{array}$ & $6.41 \pm 0.09$ & $5.74 \pm 0.09$ & $1.89 \pm 0.12^{\mathrm{b}}$ & $1.71 \pm 0.10^{\mathrm{b}}$ & $1.47 \pm 0.11^{\mathrm{b}}$ & $1.12 \pm 0.10^{\mathrm{b}}$ \\
\hline
\end{tabular}

KGB: Koliform grubu bakteriler; FKGB: Fekal koliform grubu bakteriler; CB: Coliform bacteria; FCB: Fecal coliform bacteria

Yaprak peyniri florasinda ortalama Lactobacillus sp. sayısı (log kob g-1), olgunlaşma periyodunun 60. gününde düşmüş, daha sonra yükselmiştir. Benzer durum, bazı araştırıcılar (Öner ve ark. 2006, Ortigosa ve ark. 2006, Uysal 2008) tarafindan da bildirilmiştir. İnek sütünden yapılan peynirde koliform grubu bakteri yükü $\left(\log \mathrm{kob} \mathrm{g}^{-1}\right)$ çok önemli düzeyde $(\mathrm{P}<0.01)$ daha yüksek bulunmuştur (Çizelge 3). Üretim ve depolama prosesi bakımından Yaprak peyniri ile benzerlik gösteren Örgü ve Lavaş peynirleri ile ilgili yapılan farklı çalışmalarda, söz konusu peynirlerde ortalama koliform grubu bakteri sayıları, 2.50-7.91 log kob g $^{-1}$ aralığında bildirilmiştir (Özdemir ve ark. 1998, Aksu ve ark. 1999, Anar ve ark. 2000, Çelik ve ark. 2001, Türkoğlu ve ark. 2003, Vural ve ark. 2010).

İnek ve koyun sütlerinden üretilen Yaprak peyniri florasında, depolama periyodunun başlangıcında koliform grubu bakteri yükünün yüksek olduğu, ancak periyot boyunca bu yükün azaldığı ve periyodun 90 . gününde bu sayının $<1 \log k^{k b} g^{-1}$ seviyesine düştüğü görülmektedir (Şekil 6). Benzer azalma trendi, farklı peynir çeşitlerinde birçok araştırıcı tarafından da bildirilmiştir (Arıcı ve Şimşek 1991, Albenzio ve ark. 2001, Marino ve ark. 2003, Cabezas ve ark. 2007, Uysal 2008). Bu bağlamda, Diyarbakır Örgü peyniri florasında olgunlaşma periyodunun 1.gününde koliform grubu bakteri yükünün $5.55 \log$ kob g-1 olduğu, periyodun 90.gününde ise bu yükün $<1.00 \mathrm{log}$ kob g $\mathrm{g}^{-1}$ değerine düştüğü bildirilmiştir (Hatipoğlu 2014). Bu parametre bakımından, geleneksel Yaprak peynirinin taze olarak tüketilmesi tüketici sağlığı açısından risk oluşturmaktadır.

Farklı tür sütlerden üretilen Yaprak peynirinin fekal koliform grubu bakteri yükünün depolama periyodunun başlangicında yüksek olduğu, ancak periyot boyunca bu yükün azaldığı ve periyodun 90 . gününde ise $<1 \log k o b \mathrm{~g}^{-1}$ seviyesine düştüğü görülmektedir (Şekil 7). Uysal (2008) çiğ sütten yapılan Dil peyniri florasında fekal koliform grubu bakteri sayılarını olgunlaşma periyodunun başlangıcında yüksek (2.45 log kob $\left.\mathrm{g}^{-1}\right)$ olduğu, periyodun 90. gününde önemli düzeyde azaldığ (1.04 log kob g-1), Marino ve ark. (2003) pıhtısı haşlanan Montasio peyniri florasinda bu grup bakteri yükünün depolama periyodu boyunca azaldiğ 1 ve periyodun 30 .gününde $<1 \log \mathrm{kob} \mathrm{g}^{-1}(<2.54)$ düzeyine indiğini bildirmişlerdir.

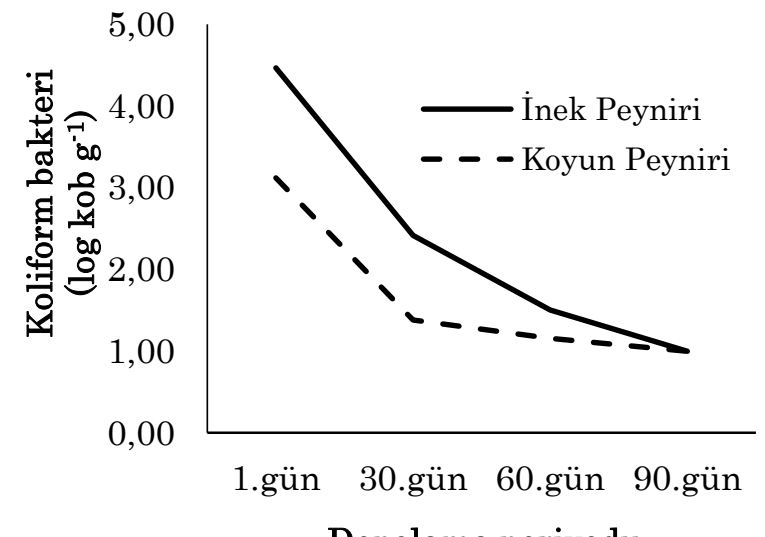

\section{Depolama periyodu}

Şekil 6. Farklı tür sütten üretilen Yaprak peyniri florasında koliform grubu bakteri yükünün depolama periyodu boyunca değişimi

Figure 6. The changes in coliform bacteria load of Yaprak cheeses made from diffrent types of milk during storage period

Koyun sütünden elde edilen Yaprak peyniri florasında E.coli yükü, çok önemli düzeyde $(\mathrm{P}<0.05)$ daha düşük bulunmuştur (Çizelge 3). Piyasadan temin edilen Örgü peyniri örneklerinde ortalama E.coli sayıları (log kob $\left.\mathrm{g}^{-1}\right) 1.63$ ve 3.69 olarak bildirilmiştir (Aksu ve ark. 1999, Vural ve ark. 2010).

Yaprak peyniri florasinda, depolama periyodunun başlangıcında $E$. coli bakteri yükünün yüksek olduğu, ancak periyot boyunca bu yükün azaldığı ve periyodun 90.gününde $<1 \quad \log$ kob $\mathrm{g}^{-1}$ seviyesine düştüğü 
görülmektedir (Şekil 8). Benzer azalma durumu, çiğ, termize ve pastörize sütten yapılan Dil peyniri florasında da bildirilmiştir (Uysal 2008). Gıdalarda bulunan E.coli ishal, ateş ve mide bulantısı semptomları gösteren gida zehirlenmesine neden olan bir bakteridir (Ünlütürk ve Turantaş 2003). Bu nedenle peynirde E.coli bakterisinin mevcut olması halinde söz konusu peynirin tüketime uygun olmadığına hükmedilir.

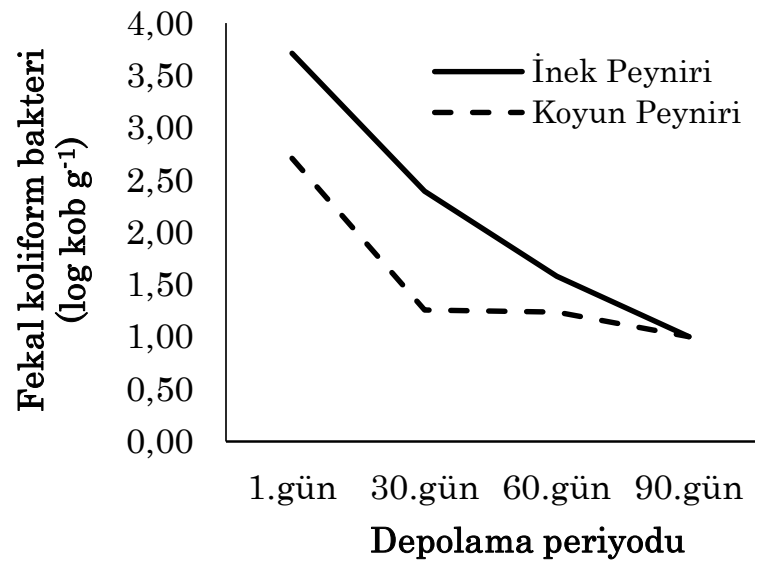

Şekil 7. Farklı tür sütten üretilen Yaprak peyniri florasinda fekal koliform grubu bakteri yükünün depolama periyodu boyunca değişimi

Figure 7. The changes in fecal coliform bacteria load of Yaprak cheeses made from diffrent types of milk during storage period

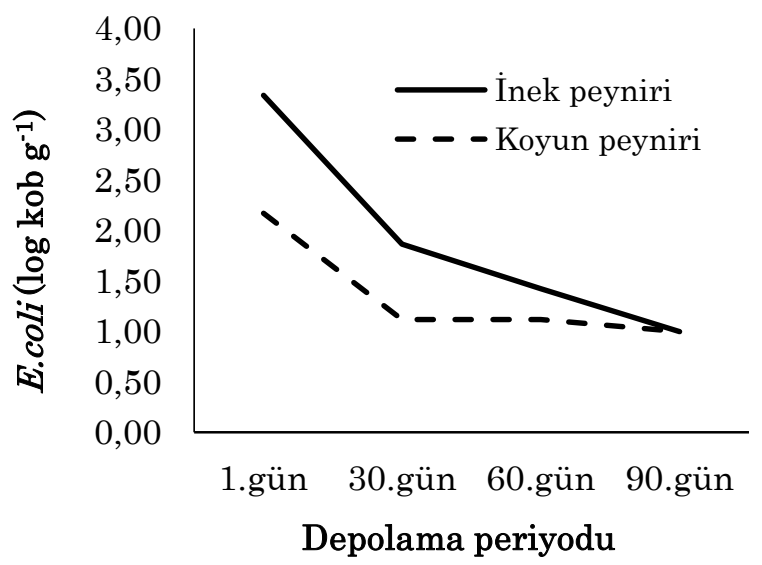

Şekil 8. Farklı tür sütten üretilen Yaprak peyniri florasında $E$. coli bakteri yükünün depolama periyodu boyunca değişimi

Figure 8. The changes in E. coli load of Yaprak cheeses made from diffrent types of milk during storage period

İnek ve koyun sütünden üretilen Yaprak peyniri florasında maya-küf yükleri, sirasıyla 2.10 ve $1.12 \mathrm{log}$ kob $\mathrm{g}^{-1}$ olarak bulunmuştur. Yaprak peyniri ile benzerlik gösteren Örgü ve Lavaş peynir floralarında farklı araştırmacıların yapmış oldukları çalışmalarda, ortalama maya küf sayısı, 2.63-5.61 log kob g-1 aralığında değiştiği bildirilmiştir (Özdemir ve ark. 1998, Aksu ve ark. 1999, Anar ve ark. 2000, Çelik ve ark. 2001, Türkoğlu ve ark. 2003, Vural ve ark. 2010, Hatipoğlu 2014). Dil peynirinde maya sayısının en fazla $4 \log$ kob g-1 $^{-1}$, küf sayısının ise en fazla $3 \log \mathrm{kob}$ $\mathrm{g}^{-1}$ olabileceği bildirilmiştir (Anonim 2006). Bu bağlamda, üretim ve muhafaza şekli itibarı ile Dil peyniri ile benzerlik gösteren Yaprak peynirinde, depolama periyodunun ilk gününden itibaren mayaküf sayısı açısından hem standarda hem de tebliğe uygunluk arz etmiştir.

Geleneksel Yaprak peyniri florasında maya-küf sayısı, depolama periyodunun 30.gününde yükselme, takip eden periyotta ise sürekli bir azalma göstermiştir (Şekil 9). Benzer durum, pek çok araştırıcı tarafından da bildirilmiştir (Gerasi ve ark. 2003, Manolopoulou ve ark. 2003, Marino ve ark. 2003, Öner ve ark. 2006, Uysal 2008). Olgunlaşma periyodunun sonuna kadar maya-küf popülasyonunun varlı göstermesi, bu mikroorganizmaların geniş bir su aktivitesi aralığında (aw: 0.65-0.90), düşük pH (bazı durumlarda $\mathrm{pH}$ 3'ün altında) ile sicaklık derecelerinde gelişebilme yeteneklerine bağlanabilir (Durlu-Özkaya ve Cömert 2008).

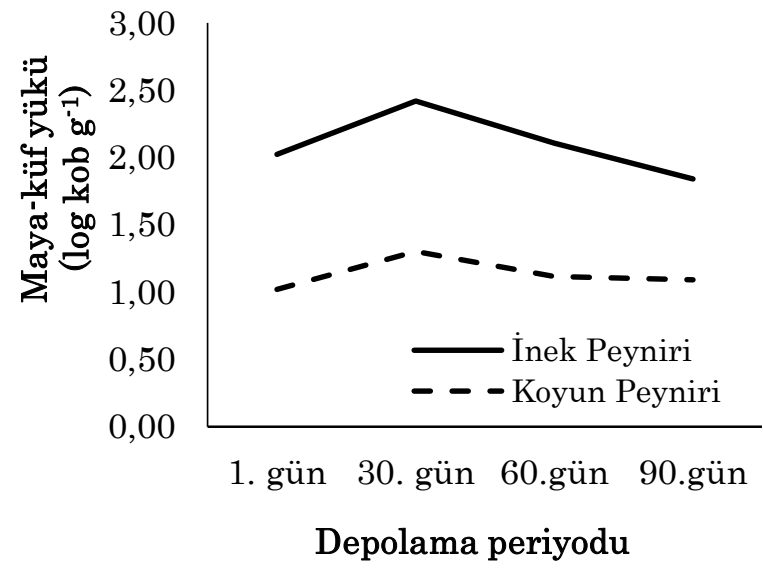

Şekil 9. Farklı tür sütten üretilen Yaprak peyniri florasında maya-küf yükünün depolama periyodu boyunca değişimi

Figure 9. The changes in mould and yeast load of Yaprak cheeses made from diffrent types of milk during storage period

Yaprak peyniri örneklerinde koagülaz pozitif $S$. aureus, depolama periyodunun 1. gününde yapılan ekimler ve alınan izolatların değerlendirilmesi sonucunda, sadece 3 adet inek sütünden üretilen peynirde, periyodun 30. gününde ise bu örneklerin sadece 1 adedinde tespit edilmiştir. Koyun sütünden yapılan Yaprak peyniri örneklerinde ise koagülaz pozitif $S$. aureus bakterisine rastlanılmamıştır. Koagülaz pozitif $S$. aureus bakteri yükü, izin verilen değerden $\left(<10^{3}\right.$ adet $\left.\mathrm{g}^{-1}\right)$ daha düşük bulunmuştur (Anonim, 2011). 


\section{SONUÇ ve ÖNERILLER}

İnek ve koyun sütünden üretilen Yaprak peynirinin KM oranı bakımından, Türk Gıda Kodeksi Peynir Tebliğ̣ine uygunluk arz ettiği; KM'de yağ oranı bakımından inek sütünden elde edilen peynirin tam yağlı, koyun sütünden elde edilen peynirin ise yarım yağlı peynir; anılan tebliğ bağlamında Yaprak peynirinin sert peynir sınıfında yer aldığı; KM'de tuz oranı bakımından ise, peynirin tebliğde izin verilen orandan daha yüksek düzeyde tuz içerdiği tespit edilmiştir.

Her iki süt türünden yapılan Yaprak peyniri florasında mikrobiyal kontaminant olarak anılan ve aynı zamanda gıda güvenliği indikatörü olarak kabul edilen koliform, fekal koliform, E. coli ve maya-küf yükleri bakımından periyodun 90. gününde riskin minimize olduğu $\left(<1\right.$ log kob $\left.\mathrm{g}^{-1}\right)$ ve dolayısıyla tüketilebileceği sonucuna varılmıştır. Diğer taraftan, inek ve koyun sütünden üretilen taze Yaprak peynirinin Türk Gıda Kodeksi Mikrobiyolojik Kriterler Yönetmeliği’ne (Anonim 2011) uygunluk arz ettiği sonucuna varılmıştır.

Geleneksel Yaprak peyniri kendine has tat-aroma ve tekstürü nedeniyle gün geçtikçe bu peynire talebin arttığı, dolayısıyla söz konusu peynirin doğal karakteristik niteliklerini kaybetmeden endüstriyel üretime kazandırılması gerektiği düşünülmektedir. Ancak laboratuvar çalışmaları sonucunda elde edilen verilerden anlaşıldığı üzere, Geleneksel Yaprak peyniri bileşiminin farklılık gösterdiği, dolayısıyla üretimin standardize edilmesi gerektiği düşünülmektedir. Bu bağlamda, peynir üretiminde sütün yağ oranı, mayalama süresi ve sicaklı̆̆ı, fermente telemenin haşlama asitliği, haşlama suyu sicaklık ve süresi, salamuranin tuz oranı, olgunlaştırma şartları (sıcaklık ve süre açısından) gibi prosesler bakımindan standardize edilmesi önem taşımaktadır. Üretimde pastörize sütün kullanımı teşvik edilerek, söz konusu peynirin karakteristik özellikleri bakımından uygun starter kültür/kültürler tespit edilmelidir.

\section{TEŞEKKÜR}

Bu çalışma, Harran Üniversitesi Bilimsel Araştırma Projeleri Komisyonu Başkanlığı tarafindan finansal olarak desteklenmiştir (Proje No: 18078).

\section{Araştırmacıların Katkı Oranı Beyan Özeti}

Yazarlar makaleye eşit oranda katkı sağlamış olduklarını beyan eder.

\section{Çıkar Çatışması Beyanı}

Makale yazarları aralarında herhangi bir çıkar çatışması olmadığını beyan ederler.

\section{KAYNAKLAR}

Aksu H, Çolak H, Vural A, Erkan ME 1999. Diyarbakır Bölgesinde Üretilen Örgü Peynirlerde Mikrobiyolojik ve Kimyasal Özellikler Üzerine Bir Araştırma. YYÜ Veteriner Fak. Derg 10 (1-2): 8-11.

Albenzio M, Corbo MR, Rehman SU, Fox PF, De Angelis M, Corsetti A, Sevi A, Gobbetti M 2001. Microbiological and Biochemical Chacacteristics of Canestrato Pugliese Cheese Made from Raw Milk, Pasteurized Milk or by Heatig Curd in Hot Whey. International Journal of Food Microbiology 67 (1-2): 35-48.

Anar Ş, Soyutemiz GE, Çetinkaya F 2000. Örgü Peynirinin Üretim Aşamalarında Görülen Bazı Mikrobiyolojik ve Kimyasal Değişimler. UU Veteriner Fakültesi Dergisi 19 (1-2): 81-85.

Anonim 1989. Peynir Standardı (TS 591). Türk Standartları Enstitüsü. Ankara.

Anonim 2001. Gida ve Hayvan Yemlerinin Mikrobiyolojisi, Koagulaz Pozitif Stafilakoklarm Sayımı İçin Yatay Metot. Bölüm 1: Baird Parker Agar besiyeri kullanarak, Türk Standartları Enstitüsü, TS6582-1 EN ISO 6888-1, Ankara.

Anonim 2006. Dil Peyniri Standardı (TS 3002). Türk Standartları Enstitüsü, Ankara.

Anonim 2011. Türk Gıda Kodeksi Mikrobiyolojik Kriterler Yönetmeliği (RG 28157, 3. Mükerrer). Gıda, Tarım ve Hayvancılık Bakanlığı, Ankara.

Anonim 2015. Türk Gıda Kodeksi Peynir Tebliği (Tebliğ no: 2105/6). Gıda, Tarım ve Hayvancılık Bakanlığı, Ankara.

Arıcı M, Şimşek O 1991. Kültür Kullanımının Tulum Peynirinin Duyusal, Fiziksel, Kimyasal ve Mikrobiyolojik Özelliklerine Etkisi. Gıda 16 (10): 53-62.

Cabezas L, Sánchez I, Poveda JM, Seseña S, Palop ML 2007. Comparison of Microflora, Chemical and Sensory Charactaristics of Artisanal Manchego Cheeses from Two Dairies. Food Control 18: 11-17.

Calvo MV, Castillo I, Diaz-Barcos V, Requena T, Fontecha J 2007. Effect af a Hygienized Rennet and a Defined Strain Starter on Proteolysis, Texture and Sensory Properties of Semi-Hard Goat Cheese. Food Chemistry 102: 917-924.

Caridi A 2003. Identification and First Characterization of Lactic Acid Bacteria Isolated from Artisanal Ovine Cheese Pecorino del Poro. International Journal of Dairy Technology 56: 105110.

Coşkun H 1995. Farklı Metotlarla Üretilen Otlu Peynirlerde Olgunlaşma Süresi Boyunca Meydana Gelen Değişmeler. YYÜ Fen Bilimleri Enstitüsü Gıda Mühendisliği Anabilim Dalı, Doktora Tezi, 111 sy.

Çelik Ş, Özdemir C, Özdemir S 2001. Production Techniques and Some Properties of Traditional Lavas Cheese. Journal of Biological Science 1 (7): 603-605. 
Çelik Ş, Türkoğlu H 2007. Ripening of Örgü Cheese Manufactured with Raw or Pasteurized Milk: Composition and Biochemical Properties. International Journal of Dairy Technology 60 (4): 253-258.

Dost A, Yenikan H, Okumuş F, Işıklı ND 2004. Bazı Geleneksel Peynirlerin Üretim Yöntemleri. Geleneksel Gıdalar Sempozyumu, 23-24 Eylül, Van.

Durlu-Özkaya F, Cömert M 2008. Gıda Zehirlenmelerinde Etken Faktörler. Türk Hijyen ve Deneysel Biyoloji Dergisi 65 (3): 149-158.

FIL-IDF 1993. Milk Determination of Nitrogen Content. IDF: 2B, International Dairy Fedaration, 41: 12

Fresno M, Alvarez S 2012. Chemical, Textural and Sensorial Changes During the Ripening of Majorero Goat Cheese. International Journal of Dairy Technology 65 (3): 393-400.

Gaya P, Medina M, Rodriguez-Marin MA, Nunez M 1990. Accelerated Ripening of Ewes' Milk Manchego Cheese: The Effect of Elevated Ripening Temperatures. Journal of Dairy Science 73 (1): 2632.

Gerasi E, Litopoulou-Tzanetaki E, Tzenatakis N 2003. Microbiological Study of Manura, A Hard Cheese Made from Raw Ovine Milk in The Greek Island Sifnos. International Journal of Dairy Technology 52: $117-122$.

Gripon JC, Desmazeud MJ, Baes D, Bergere JH 1975. Etude du rôle des micro-organismes et des enzymes au cours de la maturation des fromages. Le Lait, 55 (548): 502-516.

Güven M, Konar A 1994. İnek Sütlerinden Üretilen ve Farklı Ambalajlarda Olgunlaştırılan Tulum Peynirlerinin Mikrobiyolojik Özellikleri. Gıda 19 (3): 179-185.

Hatipoğlu A 2014. Geleneksel Diyarbakır Örgü Peynirinin Karakteristik Özelliklerinin Tespit Edilmesi ve Gıda Güvenliği Açısından Değerlendirilmesi. Harran Üniversitesi Fen Bilimleri Enstitüsü Gıda Mühendisliği Anabilim Dalı, Doktora Tezi, 130 sy.

Kamber U 2005. Geleneksel Anadolu Peynirleri. Miki Matbaacılık San. Tic. Ltd. Şti., Ankara, 223sy.

Koçak C, Aydınoğlu G, Uslu K 1997. Ankara Piyasasında Satılan Dil Peynirlerinin Proteoliz Düzeyi Üzerinde Bir Araştırma. Gıda 22 (4): 251255.

Manolopoulou E, Sarantinopoulos P, Zoiidou E, Aktypis A, Moschopoulou E, Kandarakis IG, Anifantakis EM 2003. Evolution of Microbial Populations During Traditional Feta Cheese Manufactura and Ripening. International Journal of Food Microbiology 82 (2):153-161.

Marino M, Maifreni M, Rondinini G 2003. Microbiological Characterization of Artisanal Montasio Cheese: Analysis of It's Indigenous Lactic Acid Bacteria. FEMS Microbiological Letters 229
(1): $133-140$.

Mcsweeney PLH, Fox PF, Lucey J A, Jordan K N, Cogan T M 1993. Contribution of The Indigenous Microflora to The Maturation of Cheddar Cheese. International Dairy Journal 3: 613-634.

Moatsou G, Kandarakis I, Moschopoulou EI, Anifantakis E, Alichanidis E 2011. Effect of Technological Parameters on The Characteristics of Kasseri Cheese Made From Raw or Pasteurized Ewes' Milk. International Journal of Dairy Technology 54 (2): 69-77.

Ortigosa M, Arizcun C, Irigoyen A, Oneca M, Torre P 2006. Effect of Lactobacillus Adjunct Cultures on the Microbiological and Physicochemical Characteristics of Roncal-Type Ewes' Milk Cheese. Food Microbiology 23: 591-598.

Öner Z, Karahan AG, Aloğlu H 2006. Changes in the Microbiological and Chemical Characteristics of an Artisanal Turkish White Cheese During Ripening. LWT Food Science and Technology 39 (5): 449-454.

Özdemir S, Çelik Ş, Özdemir C, Sert S 1998. Diyarbakır'ın Karacadağ Yöresinde Mahalli Olarak Yapılan Örgü Peynirinin Mikrobiyolojik ve Kimyasal Özellikleri. V. Süt ve Süt Ürünleri Sempozyumu, 21-22 Mayıs, Tekirdağ.

Rosenberg M, Wang Z, Chuang SL, Shoemaker CF 1995. Viscoelastic Property Changes in Cheddar Cheese During Ripening. Journal of Food Science 60 (3): 640-644.

Sert D, Ayar A, Akın N 2007. The Effects of Starter Culture on Chemical Composition, Microbiological and Sensory Characteristics of Turkish Kasar Cheese During Ripening. International Journal of Dairy Technology 60 (4): 245-252.

Tarakçı Z, Küçüköner E 2006. Changes on Physicochemical and Proteolysis of Vacuum-Packed Turkish Kasar Cheese During Ripening. Journal of Central Europe Agricultural 7 (3): 459-464.

Türkoğlu H, Ceylan ZG, Dayisoylu K S 2003. The Microbiological and Chemical Quality of Örgü Cheese Produced in Turkey. Pakistan Journal of Nutrition 2 (2): 92-94.

Uysal Ş 2008. Dil Peyniri Üretiminde Doğal Termofilik Peyniraltı Suyu Kültürünün Kullanım Olanağının Araştırılması. Harran Üniversitesi Fen Bilimleri Enstitüsü Gıda Mühendisliği Anabilim Dalı, Yüksek Lisans Tezi, 91 sy.

Üçüncü M 2004. Süt ve Mamulleri Teknolojisi. Meta Basım Matbaacılık Hizmetleri, İzmir, 571 sy.

Ünlütürk A, Turantaş F 2003. Gıda Mikrobiyolojisi. Meta Basım Matbaacılık Hizmetleri, İzmir, 606 sy.

Vural A, Erkan ME, Guran HŞ 2010. The Examination of the Microbiologic Quality in Örgü Cheese (Braided Cheese) Samples. KÜ Veteriner Fakültesi Dergisi 16 (Suppl-A): 53-58.

Yıldız N, Bircan H 1994. Araştırma ve Deneme Metotları. Atatürk Üniversitesi Ziraat Fakültesi Yayın No: 305, Erzurum, 266 sy. 